Mikołaj Deckert, Monika Kocot, Aleksandra Majdzińska-Koczorowicz

University of Łódź

https://doi.org/10.18778/8220-191-8.01

\title{
Moving between Modes - Intersemioticity, Translation and Interdisciplinarity
}

What can be termed "intersemiotic translation" has functioned as an exciting subject of inquiry but the line of work is still in its forming stage. Therefore, and for reasons that will be partly given below, there is clearly a need for more research but also critically for the existing research findings to be integrated cross-disciplinarily as well as systematised.

Partly given the gradable matching of terms, and because of the variable scope of themes under scrutiny, the term used in the current volume's subtitle - "intersemiotic translation" - does not need to be explicitly employed for a research effort or output to be tackling topics with close affinity to the ones covered here. With that in mind, some of the relevant publications will range from papers (Clüver 1989; O'Halloran, Tan and Wignell 2016) and edited books (Oittinen, Ketola and Garavini 2017; Salmose and Elleström 20201) to single-author monographs (Sager Eidt 2008; Pârlog 2019). Along those lines, to contextualise the current book, it should be highlighted that the research presented here ties in with an array of other vibrant subfields. One will be multimodality, ${ }^{2}$ extensively researched for example within the paradigm of cognitive linguistics (Dancygier and Sweetser 2012; Sanz 2015). Another is audio description (cf. e.g. Remael, Reviers and Vercauteren 2014; Matamala and Orero 2016), functioning more and more prominently as a mode of media accessibility provision, therefore proving that research of the type documented in the current volume can have significant societal implications.

${ }^{1}$ Notably, this volume was published in Routledge's book series devoted specifically to multimodality.

2 Professor Kwiatkowska acknowledges that "(w)hile mono-modal research is the tradition in academic study, intermodal or cross modal research is its much younger sister, and the contributors to this volume still have a chance to set some new standards as pioneers in this enterprise". These words remain true even though some time has passed since the claim was originally formulated. 
In light of the explanation provided in this volume's introductory note, Professor Alina Kwiatkowska managed to draft fragments of what she intended to include in the book's opening. The current text therefore uses some of those passages to further acknowledge Professor Kwiatkowska's being the impetus behind this publication. To begin with, the original editor remarks as follows:

The present collection of papers was inspired by the international conference on Intersemiotic Translation held at the University of Łódź in 2013. Organized by the Institute of English Studies, it brought together many enthusiastic participants, who gathered to discuss the issues that many traditional scholars would consider to be niche and rather exotic. The volume includes a selection of papers from that conference, complemented by some additional contributions.

While the line-up of contributors is slightly altered compared to that of 2013, due to practical reasons, it remains a valid point that the authors:

include linguists, literary scholars, and media scholars, who represent various approaches to the study of intersemiotic / intermodal / crossmodal interactions or translation of texts (be it linguistic, visual, or musical). They are all united, however, by their interest in exploring the processes and mechanisms involved in moving meaning between modes, especially the meaning of the subtle and non-obvious kind arising from creative activity. Research in this field must naturally cross - the borders of disciplines - only the integration of insights from different areas of expertise may lead to the broadening of our understanding of this complex and heterogeneous field.

Indeed, interdisciplinarity is the current volume's major asset and is reflected in the "variety of research interests and points of departure, of the subjects and materials chosen for analysis, but also of the employed methods of research". Professor Kwiatkowska talks about not fitting "the traditional 'pigeonholes' of disciplines or levels of analysis" as holding the promise of development and originality in research and alludes to the conceptual integration theory (cf. Fauconnier and Turner 2002), pointing out that "different points of view and different descriptive tools make up a colorful whole; they become input spaces in a fascinating blend".

One demarcation that has traditionally been clear is between linguistics and literary studies. While their respective tenets and foci will be differently similar on different occasions, it is possible for these disciplines to cross-feed. ${ }^{3}$ And this, we would argue, is what the current volume accomplishes, even if the orientation will naturally be more

${ }^{3}$ These distinctions are also acknowledged in a recent publication devoted to intersemiotic translation (Pârlog 2019) whose subtitle reads "Literary and Linguistic Multimodality", thus stressing the need to interface approaches, which has been a vital source of motivation for our volume. 
towards one or the other - a point expressed by Professor Kwiatkowska talking about "the relative neglect of non-literary discourse" which, as she goes on to clarify, is rather natural "considering how much of the inspiration for the research in this field to date has come from the scholars with a literary background". Literary studies and linguistics being just one prominent example, other cases of cross-fertilisation to be mentioned include visual arts, performing arts, semiotics, media studies, philosophy, poetics and stylistics.

At the same time, as the need for diversity in thinking about research subjects is here acknowledged and encouraged, one should keep in mind the risk of inconsistency which cross-disciplinarity might bring when approaches are collated. Professor Kwiatkowska was well-aware of that and the following remark of hers is just one example to argue that the current volume does not suffer from ill-conceived heterogeneity - "despite this variety and originality, the authors [...] have several authorities whose writings recur in the reference sections of their papers, and that they are also aware of one another's work".

A related issue to heed would be of terminological-conceptual nature which Professor Kwiatkowska identifies even with respect to the key notion of "intersemiotic translation" that "has been around for some time" and yet "the use of other terminology having to do with intermodal relations has been somewhat erratic". A similar question appears to be relevant when it comes to the possible differentiation between polysemioticity and multimodality, with the formulations of what constitutes a "modality" - as possibly discernable from "mode" - not necessarily overlapping across disciplines or even researchers working within fairly narrow subfields (cf. Zlatev 2019).

The book opens with a text by Barbara Lewandowska-Tomaszczyk - one that is both personal and scholarly - tellingly titled "Remembering Alina Kwiatkowska". Then, we follow with four parts around which this volume is organised, starting with "Theoretical Reflection", through "Modes of Literature" and "The Interfaces of Music" to conclude with "Performance". The contributions accommodated in these respective sections are briefly outlined below.

The first part of the volume, entitled "Theoretical Reflection", features five chapters each of which discusses a different aspect of intersemiotic translation theory. It starts with Lars Elleström's chapter "Media Transformation: The Transfer of Media Characteristics between Media" which aims to develop a new theoretical framework for the study of media characteristic transfer, which Elleström calls media transformation. The goal of the framework is to explain what happens when meaningful 
data is changed or corrupted during transfer among different media, and how an in-depth understanding of such processes may influence understanding communication. In his chapter "From Translation to Intersemiosis: A Journey across Expressive Modalities", José Sanjinés uses an unfolding metaphor for journeys articulated in the context of translation and intersemiosis in order to discuss different theories and approaches in a synchronic perspective. Marta Kaźmierczak's chapter "From Intersemiotic Translation to Intersemiotic Aspects of Translation" sketches the distinction between several allied and complementary notions related to intersemioticity, polysemioticity and translation, and illustrates it with examples pertaining to the proposed categories. This section concludes with Magdalena Wasilewska-Chmura's chapter "Why Intersemiotics Isn't Enough? Remarks on Intersemiotic and Intermedial Studies". As a literary scholar with a musicological background, Wasilewska-Chmura demonstrates her own search for adequate tools to explore artistic projects of a transgressive nature, commonly referred to as borderline phenomena.

The second part of the present volume, entitled "Modes of Literature", focuses on the mechanisms underlying the production and/ or reception of intermodal literary texts. This section opens with the chapter "Between the Visible and the Legible: Raymond Pettibon's "I" Caught in Translation" by Tilo Reifenstein who reasserts the inexorable affinity and proximity between the verbal and the visual in Pettibon's work while questioning some persistent notions on the differences between language and non-verbal sign systems. Monika Kocot's "From Broken Communication to the Technique of (Linguistic) Anamorphosis. Edwin Morgan's Concrete Poetry" studies various examples of playful intersemiotic translation in Edwin Morgan's verbivocovisual poetry with an emphasis on a number of aesthetic traditions that inform Morgan's writing. In her chapter "Perception and Conceptualization of Visual Arts in Ekphrastic Poetry", Anna Szczepanek-Guz employs a cognitive poetics approach to look at a poem by Donald Hall who ekphrastically represents The Scream by Edvard Munch. This section concludes with two chapters on Franciszka and Stefan Themerson. Agnieszka Taborska's "Franciszka Themerson and the Gaberbocchus Press: Bestlookers versus Bestsellers" looks at fascinating examples of intersemiotic experimentation in the Gaberbocchus Press whereas Marcin Giżycki's “Bacon, Friedman, Themerson or How to Translate Anything to Anything" traces the history of the Baconian-Friedman ciphering, and shows that the practice of translating anything to anything has found its way to poetry, painting, and experimental cinema, as can be exemplified by Stefan Themerson's Semantic Poetry. 
The third part of the volume, entitled "The Interfaces of Music", foregrounds music as a mode of expression. It opens with Elżbieta Górska's chapter "From Music to Language and Back" focusing on an intermodal translation from music to language and back on the basis of Daniel Barenboim's BBC Reith Lectures of 2006. Marcin Stawiarski in his "Vocal Intersemioticity in James Chapman's How Is This Going to Continue?" employs Roman Jakobson's understanding of intersemiotic translation as transmutation from one sign system to another, analysing two works belonging to different modalities, namelyAlois Zimmermann's composition Requiem für einen jungen Dichter (1969) and James Chapman's novel How Is This Going to Continue? (2007). Karen Wilson-deRoze's paper “Mixed Signals: How German Lieder, as Multimodal Texts, Present Particular Challenges for Translators" also concerns the literature-music interface, presenting the problems that can be encountered in translating songs with reference to German Lieder. Joanna Barska in her paper "Love Old Sweet Song: How Joyce Narrativizes with Music?" pursues the motif of music and musicality inscribed into James Joyce's Ulysses. In a more theoretical vein, Elena Aznacheeva and Yulia Mamonova ("The Verbalization of Music in Fiction") conclude the section with discussing the issue of literature musicality understood as mutual transposition of semantic and aesthetic information from music into fiction.

The collection finishes with considerations concerning "Performance". Izabela Szymańska presenting a chapter "On the Analogies between Translation and Film Adaptations of Literary Classics" reflects on an analogy between interlingual translation and film adaptations of classical novels in the context of intersemiotic translation. In her analysis entitled "The Ending of Great Expectations according to South Park: A Science-Fictional Revisitation", Claudia Cao investigates an episode of South Park dedicated to Great Expectations by Charles Dickens, presenting it as a science-fictional rereading that modernizes the original story. Adopting a more philosophical approach, Jadwiga Uchman ("A Philosophical Debate on the Screen - Bishop Berkeley's Esse Est Percipi and Samuel Beckett's Film") discusses the influence of George Berkley's thought on Film by Samuel Beckett. Eva Bubnášová ("Between Text and Performance: On the Productive Reception of H. C. Andersen's Fairy Tales by the Slovak Radio") attempts to describe similarities and differences between H. C. Andersen's fairy tales and their radio plays by the Slovak Radio. Continuing the subject of radio drama, Łukasz Borowiec in his chapter "Inside Noise: Intersemiotic Translation and Metatheatre in Radio Drama" analyses how various semiotic systems work inside a radio play on the basis of the BBC radio production entitled Noise (2012) by Alex 
Bulmer. James Moir focuses on the semiotic aspects of nonverbal features of communication presenting "Reading the Signs: Intersemiocity and NonVerbal Communication". Teresa Bruś closes the volume with a semiotic reflection on the aspects of serialization and multiplication of Stanisław Ignacy Witkiewicz's portrait representations and their photographic transpositions ("Serialization and Multiplication in Portraiture: Stanisław Ignacy Witkiewicz and Photographic Translations").

To briefly sum up, let us draw on Professor Kwiatkowska's words once more as she emphasises the evolving nature of research topics like the one captured by the contributors to this volume:

This area of study is still an emerging paradigm, with scholars experimenting and asking questions rather than reaching definitive conclusions. It certainly will not be long before another collection of articles offers new hypotheses and analyses. Our volume is a link in this chain.

\section{References}

Clüver, Claus (1989). “On Intersemiotic Transposition”. Poetics Today 10 (1): 55-90. Dancygier, Barbara and Eve Sweetser (eds.) (2012). Viewpoint in Language: A Multimodal Perspective. Cambridge: Cambridge University Press.

Fauconnier, Gilles and Mark Turner (2002). The Way We Think: Conceptual Blending and the Mind's Hidden Complexities. New York: Basic Books.

Matamala, Anna and Pilar Orero (eds.) (2016). Researching Audio Description: New Approaches. Basingstoke: Palgrave.

O'Halloran, Kay L., Sabine Tan and Peter Wignell (2016). "Intersemiotic Translation as Resemiotisation: A Multimodal Perspective". Signata-Annals of Semiotics 7: 199-229.

Oittinen, Riitta, Anne Ketola, and Melissa Garavini (eds.) (2017). Translating Picturebooks: Revoicing the Verbal, the Visual and the Aural for a Child Audience. New York and London: Routledge.

Pârlog, Aba-Carina (2019). Intersemiotic Translation: Literary and Linguistic Multimodality. Basingstoke: Palgrave.

Remael, Aline, Nina Reviers and Gert Vercauteren (eds.) (2014). Pictures Painted in Words. ADLAB Audio Description Guidelines. Available at: http://www. adlabproject.eu/home/ [accessed Jan. 10, 2020].

Sager Eidt, Laura M. (2008). Writing and Filming the Painting: Ekphrasis in Literature and Film. Amsterdam and New York: Rodopi.

Salmose, Niklas and Lars Elleström (2020). Transmediations: Communication across Media Borders. New York and London: Routledge. 
Sanz, María Jesús Pinar (ed.) (2015). Multimodality and Cognitive Linguistics. Amsterdam and Philadelphia: John Benjamins.

Zlatev, Jordan (2019). "Polysemiotic Communication vs. Multimodality: Narration, Pantomime, and Metaphor". Plenary talk at the annual Polish Cognitive Linguistics Association conference "Cognitive Linguistics in the Years 2019", 26-28 September 2019, Białystok. 